\title{
Cultural Attributes of Students to Make Student-Centered Approach Successful
}

\author{
Olga A. Filatova
}

\begin{abstract}
Student-centered approach to teaching and flipped classrooms have recently become a focus of on-going teaching discussion. They are powerful tools in helping students to develop their language and interpersonal communication skills, promote cooperation, academic curiosity, responsibility, and active and deep learning. We will focus on student attributes specific to culture that should be taken into consideration when teaching students native of different areas namely from Arabic, Asian and South American and Eastern European countries when teaching in a student centered classroom. Although the examples are from teaching English as a second or foreign language to students of above mentioned nationalities in an Intensive English Language program at an American University setting, the author believes that general principles can be applied to teaching other disciplines to international students.
\end{abstract}

Index Terms-Attributes specific to cultures, independent work, project learning, student centered learning.

\section{INTRODUCTION}

Student-centered approach to teaching and flipped classrooms have been discussed as early as 1983 [1], but recently became a focus of many professional journal publications and conference presentations [2]-[7]. Some of many definitions describe it as flexible learning [8], experiential learning [9], self-directed learning [1] and achievement learning [10]. All these and many other definitions place emphasis on a student "doing" and being "active" rather than a teacher "transferring the knowledge" and a student "acquiring" it. Here, we will define student centered approach to teaching as a method when a student is placed in the center of learning and he /she is active, learns while being engaged in an activity, and bears primary responsibility for the outcomes of this activity. It is a Western approach to learning and may not necessarily transfer to other countries with different learning cultures [11]. Therefore, here we will focus on some student attributes specific to culture that should be taken into consideration when teaching students native of different areas namely from Arabic, Asian and South American and Eastern European countries when teaching in a student centered classroom. Although the examples are from teaching English as a second or foreign language to students of above mentioned nationalities in an Intensive English Language program at an American University setting, the author believes that general principles can be applied to teaching other disciplines to international

Manuscript received September 4, 2014; revised January 5, 2015.

Olga A. Filatova was with Northern Kentucky University, Highland Heights, KY, 41099, USA. She is now with American English and Culture Program and the Department of English, Miami University, Oxford, $\mathrm{OH}$, 450056, USA (e-mail: filatoo@miamioh.edu). students.

\section{ACTIVITIES, BENEFITS AND PRINCIPLES}

Examples of student-centered activities in an ESL classroom can include independent projects, group discussions, debates, field-trips, student class presentations, reflective diaries and learning journals, computer assisted learning, role play, poster presentations, producing mind maps, designing portfolios, writing newspaper articles, peer-mentoring of other students, flipped classroom activities and choosing subjects for study and projects. Some of these activities can take as long as the whole semester (for example, creating writing portfolios), the whole day (for example, field- trips), or as short as several minutes of a class period (for example, peer-mentoring of other students) (Appendix I, II). Lea points out several benefits of student-centered learning that include "the reliance on active rather than passive learning, an emphasis on deep learning and understanding, increased responsibility and accountability on the part of the student, an increased sense of autonomy in the learner, an interdependence between teacher and learner, mutual respect within the learner teacher relationship, and a reflexive approach to the teaching and learning process on the part of both teacher and learner"[12]. Keeping these benefits in mind, we can summarize some of the principles that should be followed. They include positive interdependence of students on one another with individual accountability for different steps and overall results of the project, face to face interactions and therefore development of interpersonal communication skills, and finally, self-assessment and self-correction on the part of students. Some of the challenges of student-centered teaching are additional preparation and restructuring of teaching time on a teacher's part and resentment of the approach on a student's part due to individual or cultural attributes. Now we will discuss how to deal with certain cultural differences to make the approach successful.

\section{Cultural Learning Attributes of Students NATIVE OF SAUDI ARABIA AND MIDDLE EAST}

Major characteristics for this group that could present challenges to student-centered learning are great cultural differences in study and behavioral expectations between Eastern and Western educational systems, a tradition of enforced hierarchy in an Arabic classroom, and rigid gender roles that affect classroom behavior.

Since Middle Eastern culture is very different from Western culture, adjustment may be difficult to some students, 
which can result in their withdrawal or hesitation to participate in classroom learning. Setting clear expectations, giving specific directions and guidelines help students to assimilate and be successful at learning. For example, students should know how and when exactly the project should be completed, what is expected in terms of independent work and accountability, what parts of assignment are negotiable and non-negotiable. Many students are likely to be unfamiliar with Western European standards of learning and will try to stretch the boundaries of due dates, amount of independent work, make-up assignments, punctuality and plagiarism. Middle Eastern culture is a collective culture, so some students may want to cover for one another with some of them doing more work than others, but requiring equal grade for the group. Weaker language speakers may experience culture shock and hesitate to participate at all. From the author's experience, letting Arabic students help each other "officially" works well for them. Peer help and mentoring, pair work and small group discussions help to overcome this cultural difference. Weaker students could be assigned a project together with stronger students where the later will have to explain and help, and the former will report what they have learned from the experience.

In their native countries students are expected to adhere to teachers' directions and an enforced hierarchy in the classroom. Students are not used to independent study groups or group work outside of the classroom. The assignment where a student has to do his/her portion of work, share it with another student who has to add something to it, then transfer it to another student, etc.(for example, working on Google doc.) may not work right away with students from Middle East. They should be slowly introduced to the concept of collective and individual accountability for the project with modeling it during the class time. Student-centered activities that will introduce students to the concept could include group teaching, poster sessions and power point presentations. In group teaching, a student could choose a topic of interest and then shares it with a group. Other group members would have to summarize a student's presentation, answer comprehension questions or assess it. Similarly, students can divide a grammar rule, where each student teaches a part of it with his/her own examples to the rest of the group. Arabic students are usually strong speakers, so individual power point presentations work well. Poster presentations help students to work on improving their weak points (usually writing) and build on their strong points (speaking). Upon successful completion of the above mentioned projects, later on during the semester, projects with more inter accountability and responsibility, like creating a group video project, writing a newspaper article, or reporting on a field trip, could be introduced.

Students have rigid gender roles that affect their classroom interactions. This mostly affects women, since they usually sit separately from men, speak in a very soft voice (whispering group), avoid speaking in front of the group or participate in peer activities that include opposite sex. Slow introduction to group activities is the key to overcoming student resentment. First, students can be asked to work on a project in a group of same sex and same origin. Once students are comfortable with group work, a female student with a different first language could join the group. A non-Arabic man can join the group next. And finally, a group of mixed sexes and first languages can be formed. Similar steps could be taken to help to the class from their seats and finally in front of the whole class. However, some students never get comfortable in mixed groups and speaking in front of the crowd, so that will limit their experience at a Western University and a number of student-centered activities that they will participate in. Although the author believes that a teacher should do everything to help students fully experience Western academic setting, reasonable accommodations should be made for this group.

\section{Cultural Learning Attributes of Students NATIVE OF ASIAN COUNTRIES}

Major characteristics for this group that could present challenges to student-centered learning are high competitiveness of Asian students, their focus on grades rather than learning, and a tradition of a teacher-centered classroom in Asian educational system.

Asian students are usually quite familiar with researching information, memorizing, practicing, and doing a fair amount of homework. Therefore, they can be very successful at student-centered projects. They are also highly competitive, which is not always a downside. Healthy competition adds to the quality of projects and motivates students to work harder. Working on group projects, competition between the groups is inevitable, and it stimulates good work. To avoid competition between members in a group, students should choose their own teammates whenever possible. Another way so shift students' attention from competition to cooperation is to check their work at midpoint when each individual student has completed his/her part of independent work and it is time to put all the information together and write, for example, a collective article, or put a presentation together. Students will know that a teacher is aware of each individual contribution to the project, and would fairly assess both: individual contribution and the final project's outcome.

Some students focus more on competition rather than personal improvement. For example, creating writing portfolios, they would be interested in their peers' grades rather than in exploring their own writing. Emphasis on individual progress helps to overcome this challenge. For example, a grade could be given for personal improvement. Students could be asked to compare a paper from the beginning of the semester with the paper from the end. They would need to analyze; for example, how their writing style has changed, what areas of improvement they could indicate, what they should focus on next, etc. A brief self-reflection at the end of each project also helps. Students could point out what they personally have learnt from the project and how that helped them in achieving their educational goals.

Some Asian students focus on grades and marks rather than learning and giving advice. To avoid this challenge, team member individually or collectively can distribute the total points for an assignment among themselves in proportion to the effort each one put in. They can also assess other groups, filling out assessment sheets provided by the teacher. For example, they can evaluate other groups' projects based on 
the quality of content, organization and presentation (Table I).

\begin{tabular}{|c|c|c|c|}
\hline \multicolumn{4}{|c|}{ TABLE I: PRESENTATION ASSESSMENT RUBRIC } \\
\hline Presentation & $\begin{array}{l}\text { Presenter } \\
\text { demonstrated } \\
\text { poor to fair } \\
\text { presentation } \\
\text { skills. No } \\
\text { practice was } \\
\text { evident. }\end{array}$ & $\begin{array}{l}\text { Presenters } \\
\text { overall } \\
\text { demonstrated } \\
\text { good } \\
\text { presentation } \\
\text { skills, but could } \\
\text { have practiced } \\
\text { more to perfect. }\end{array}$ & $\begin{array}{l}\text { Presenters had } \\
\text { very few to zero } \\
\text { speaking } \\
\text { mistakes \& used } \\
\text { their time } \\
\text { efficiently. }\end{array}$ \\
\hline Content & $\begin{array}{l}\text { Presentation } \\
\text { contained little } \\
\text { to no valuable } \\
\text { material. The } \\
\text { presentation } \\
\text { did not meet } \\
\text { the content } \\
\text { requirements. }\end{array}$ & $\begin{array}{l}\text { Presentation } \\
\text { had valuable } \\
\text { material, but } \\
\text { overall the } \\
\text { presenter could } \\
\text { have provided } \\
\text { more details in } \\
\text { his/her } \\
\text { explanations. } \\
\text { The presenter } \\
\text { was somewhat } \\
\text { convincing, but } \\
\text { I feel I need } \\
\text { more } \\
\text { explanations. }\end{array}$ & $\begin{array}{l}\text { Presentation had } \\
\text { an exceptional } \\
\text { amount of } \\
\text { valuable } \\
\text { material \& } \\
\text { demonstrated } \\
\text { knowledge of the } \\
\text { problem and } \\
\text { solution, and } \\
\text { targeted } \\
\text { audience. }\end{array}$ \\
\hline Organization & $\begin{array}{l}\text { Presentation } \\
\text { showed } \\
\text { minimal signs } \\
\text { of proposal } \\
\text { organization. }\end{array}$ & $\begin{array}{l}\text { Presentation } \\
\text { was overall } \\
\text { organized but } \\
\text { the presentation } \\
\text { could have been } \\
\text { tweaked to flow } \\
\text { better. }\end{array}$ & $\begin{array}{l}\text { Presentation was } \\
\text { very organized \& } \\
\text { flowed well from } \\
\text { one point to the } \\
\text { next. It followed } \\
\text { the structure of } \\
\text { the pitch } \\
\text { thoroughly. }\end{array}$ \\
\hline
\end{tabular}

Asian students are used to teacher centered approach and sometimes resent taking control over learning. Some of them are shy and do not participate until being called on. One way to overcome this challenge is to call randomly on individual team members to present sections of project reports or partial solutions to problems, with everyone in the group getting a grade based on the selected student's response. A teacher can also actively conference with individual students giving them a chance to report their findings in one-on-one sessions, validate their progress, and give directions and guidance for further work.

\section{Cultural Learning AtTributes of Students Native OF ABOVE MENTIONED COUNTRIES AND THE SOUTH AMERICAN AND EASTERN EUROPEAN COUNTRIES}

Major characteristics for this group that could present challenges to student-centered learning are easy opportunities for free rides for some students, cultural differences in assessment, and building on strengths at the expense of working on weaknesses.

Students coming from different cultures are used to spend different amounts of time on preparation and homework. Group work offers opportunities for some students to barely participate in preparation for the project, background research or active writing, yet get a good grade for the work mostly done by other group members. A group might be "generous" sharing a grade with a student, covering up for him/her, accepting excuses for not participation and crediting him/her with minor organizational or decoration work. Some ways to avoid this situation is to ask students to assess each other participation and distribute credit, check students' work at midpoint to assess individual contribution, ask them to write a short summary of the project at the end, or assign roles with fair and equal distribution of workload at the beginning. Students in mixed cultural groups are also more likely to be dissatisfied by being slowed down by weaker teammates. A teacher could explain to them that that the best way to learn something is to teach it, so peer tutoring works well for this group.

TABLE II: SELF-ASSESSMENT AND PEER-EDITING WRITING RUBRIC

\begin{tabular}{|c|c|c|c|}
\hline Feature & Excellent & Fair & $\begin{array}{c}\text { Needs } \\
\text { Improvement }\end{array}$ \\
\hline $\begin{array}{c}\text { Title } \\
\text { Formatting }\end{array}$ & $\begin{array}{l}\text { Intriguing and } \\
\text { relevant } \\
\text { Proper formatting } \\
\text { (5) }\end{array}$ & $\begin{array}{l}\text { Relevant } \\
\text { Some elements } \\
\text { of proper } \\
\text { formatting (3) }\end{array}$ & $\begin{array}{l}\text { Irrelevant or not } \\
\text { present } \\
\text { Not formatted } \\
\text { (1) }\end{array}$ \\
\hline $\begin{array}{c}\text { Thesis/Main } \\
\text { Idea }\end{array}$ & $\begin{array}{l}\text { Focused and } \\
\text { compelling; } \\
\text { provides specific } \\
\text { direction for the } \\
\text { reader (10) }\end{array}$ & $\begin{array}{l}\text { Focused; } \\
\text { provides } \\
\text { sufficient } \\
\text { direction for } \\
\text { the reader (10) }\end{array}$ & $\begin{array}{l}\text { Provides very } \\
\text { little or no } \\
\text { direction for the } \\
\text { reader (5) }\end{array}$ \\
\hline $\begin{array}{c}\text { Content and } \\
\text { Support }\end{array}$ & $\begin{array}{l}\text { Interesting topic } \\
\text { and angle; } \\
\text { consistent use of } \\
\text { relevant, specific } \\
\text { examples and } \\
\text { details (20) }\end{array}$ & $\begin{array}{l}\text { Interesting } \\
\text { topic; some use } \\
\text { of relevant, } \\
\text { specific } \\
\text { examples and } \\
\text { details (10) }\end{array}$ & $\begin{array}{l}\text { Too broad or } \\
\text { too narrow } \\
\text { topic; vague or } \\
\text { general use of } \\
\text { examples }(5)\end{array}$ \\
\hline $\begin{array}{c}\text { Organization } \\
\text { and } \\
\text { Structure }\end{array}$ & $\begin{array}{l}\text { Compelling } \\
\text { introduction and } \\
\text { conclusion; } \\
\text { excellent use of } \\
\text { paragraphs in } \\
\text { logical order, } \\
\text { effective use of } \\
\text { topic sentences } \\
\text { and transitions } \\
\text { between the } \\
\text { paragraphs (20) }\end{array}$ & $\begin{array}{l}\text { Good } \\
\text { introduction } \\
\text { and conclusion; } \\
\text { good use of } \\
\text { paragraphs; } \\
\text { transitions } \\
\text { between the } \\
\text { paragraphs may } \\
\text { be weak; no } \\
\text { ideas out of } \\
\text { place (10) }\end{array}$ & $\begin{array}{l}\text { Random use of } \\
\text { paragraphs to } \\
\text { chunk ideas } \\
\text { together (5) }\end{array}$ \\
\hline $\begin{array}{c}\text { Written } \\
\text { Expression }\end{array}$ & $\begin{array}{l}\text { Sophisticated } \\
\text { language (10) }\end{array}$ & $\begin{array}{l}\text { Good language } \\
\text { (5) }\end{array}$ & $\begin{array}{l}\text { Unclear } \\
\text { language } \\
\text { choices (3) }\end{array}$ \\
\hline $\begin{array}{l}\text { Sentence } \\
\text { Structure }\end{array}$ & $\begin{array}{l}\text { Variety in } \\
\text { sentence } \\
\text { structure (12) }\end{array}$ & 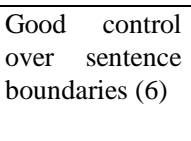 & $\begin{array}{l}\text { Needs } \\
\text { significant } \\
\text { sentence-level } \\
\text { revision (3) }\end{array}$ \\
\hline Punctuation & $\begin{array}{l}\text { Proper } \\
\text { punctuation } \\
(12)\end{array}$ & $\begin{array}{l}\text { Proper } \\
\text { punctuation for } \\
\text { the most part } \\
\text { with some } \\
\text { missed or } \\
\text { misused } \\
\text { punctuation } \\
\text { marks (6) }\end{array}$ & $\begin{array}{l}\text { Numerous } \\
\text { errors in } \\
\text { punctuation } \\
(3)\end{array}$ \\
\hline $\begin{array}{c}\text { Grammar } \\
\text { and spelling }\end{array}$ & $\begin{array}{l}\text { Good usage of } \\
\text { grammar and } \\
\text { spelling (11) }\end{array}$ & $\begin{array}{l}\text { Some mistakes } \\
\text { in grammar and } \\
\text { spelling (6) }\end{array}$ & $\begin{array}{l}\text { Misspelled } \\
\text { words and poor } \\
\text { control over } \\
\text { grammar (3) }\end{array}$ \\
\hline
\end{tabular}

Part of student-centered learning is student self- assessment and self-correction. However, when students are asked to assess their own or peers' work, students from some cultures (typically Asian) are overcritical, while from others (South America, Arabic countries) tend to credit each other with higher grades. Therefore, individual assessment doesn't give a teacher accurate feedback. One way to deal with this challenge is to ask students to work collectively on assessing the project. The other is to ask students assess the work 
according to the given rubric (Table I and Table II). Students can also be asked to give each other feedback on parts of the project. For example, they can correct punctuation or grammar mistakes in each other writing and then explain the corrections. A teacher should be the one who assigns the final grade.

Students in mixed groups tend to build on each other strength rather than overcome personal challenges. Those who are good with speaking (Arabic, South American students) tend to do most of the speaking; those who are good with reading (Asian, Eastern European students) tend to do most of the research for the group. While it works for some projects, part of student-centered learning is to improve weaknesses, so it works better for a mixed group of students if a teacher assigns roles and sets up criteria in preparation to the project and its presentation. For example, a teacher can assess each of the student's contribution to the research for the project, writing and oral presentation. A grade could be a composite of individual work on each step and a final grade for the project. The first grade can be different for each student in a group based on the quality of independent work. The last one could be the same for the whole group.

\section{CONCLUSION}

If students' cultural differences are taken into consideration, student-centered projects can be powerful tools in helping students to develop their language and interpersonal communication skills. They can help to motivate students, stimulate their leaning and facilitate acquisition of necessary language and study skills. They also help international students to adapt to cultural and academic environment of a Western University since they promote cooperation, academic curiosity, responsibility, and active and deep learning.

\section{APPENDIX I: PROJECT EXAMPLE I (SHORT)}

\section{A. Description}

Google or Blackboard Platform works well for this project. Students work in a group of three. A teacher can assign roles, but it is better if students decide on their roles themselves. The project takes about 15-20 min to complete.

Students work on Modal Verbs during a traditional teacher-centered ESL Grammar Class. At the end of the class students are given the assignment to create the advertisement for an apartment or house to rent. They are supposed to use structures and modal verbs they worked on during the class.

After a group creates the first draft of their advertisement, one student takes it home and types it. He/she uploads it on the internet platform. Other students make corrections, add or delete information. When all students agree on the wording, the second student adds pictures and makes the advertisement visually appealing. Other students can comment on it as well. The third student presents the project to the class.

\section{B. Benefits}

Students work on application of a grammar rule in a project where they have to work collectively and together be responsible for the project's outcome. They improve inter personal communication skills, work on their grammar, writing and speaking.

\section{Example}

Tired of paying a lot for a current place? New to town? Looking for comfortable living?

We have a solution for you - Dream Apartments! Our 2 and 3 bedroom apartments are incredibly comfortable and conveniently located. You can walk to a train station. You won't need to drive. Why should you be bored on weekends? You can easily walk to the shopping district with many stores, cafes and restaurants. You may also bring your pet. Small dogs and cats are welcome at Dream Apartments.

You think our apartments are expensive? They are very affordable. Call today 1-888-555-333.

\section{APPENDIX II: PROJECT EXAMPLE II (LONG)}

\section{A. Description}

A group project to record "I believe in" video based on This I Believe in website http://thisibelieve.org

Students listen to and read several "I believe in" stories, answer comprehension questions, look up vocabulary, find main ideas and supporting details and summarize stories. This work can be done independently and then shared with a group or together as a class. It works better for advanced English learners to work in a group, and weaker students to work as a class where a teacher and stronger students offer support and scaffolding.

The next step for students is to create their own brief "I believe in" statements where they list all their major beliefs. For example, their statements can include: "I believe in God. I believe in success. I believe in the power of forgiveness. I believe in a strong family. I believe in telling white lies. I believe in success......etc." At first students are asked to record their beliefs during $10 \mathrm{~min}$ and share them with a group. Later on, they polish their I believe in statements deleting and adding ideas.

The third step is to develop one of the beliefs into a descriptive essay using explanations and examples. Students can write several drafts of the essay. Each of them can be peer and teacher edited.

Finally, students record their statements and essays. One student can be an interviewer and the others can answer his/her questions about their beliefs. In this case, students collectively develop questions for the interview. An alternative for students is to just video record each other. Then students are asked to upload their videos on Blackboard and comment on three of their classmates' video casts.

\section{B. Benefits}

Doing this student-centered project, students improve their skills in the areas of listening for general idea and specific information, skimming and scanning in reading, writing a descriptive essay, free-writing, learning new vocabulary and speaking. They also develop inter personal communication and editing skills.

\section{Example}

Link to YouTube website http://youtu.be/fUOVk70WLs8 


\section{REFERENCES}

[1] C. Rogers, "The politics of education," Freedom to Learn for the 80's, Ohio: Charles E. Merrill Publishing Company, 1983.

[2] J. Bregmann and A. Sams. (January 2014). Flip your classroom: Reach every student in every class every day. International Society for Technology in Education. [Online]. Available: http://www.ascd.org/

[3] L. Bullard and R. Felder, "A student-centered approach to teaching material and energy balances, Part 2, course delivery and assessment," Chem. Engr. Education, vol. 41, no. 3, pp. 167-176, March 2007.

[4] M. Hale and E. City, "The teacher's guide to leading student-centered discussions: Talking about texts in the classroom," Thousand Oaks, Calif.: Corwin Press, 2006.

[5] V. Lee and C. Wehlburg, Inquiry-Guided Learning, John Wiley \& Sons, 2012.

[6] N. Sulla, Students Taking Charge: Inside the Learner-Active, Technology-Infused Classroom, Larchmont, NY: Eye on Education, 2011.

[7] B. Honeycutt. (2014). Flip it consulting. [Online]. Available: http://www.flipitconsulting.com/

[8] P. Taylor, "Changing expectations: Preparing students for flexible learning," The International Journal of Academic Development, vol. 5, no. 2, pp. 107-115, February 2000.

[9] P. Burnard, "Carl Rogers and postmodernism: Challenged in nursing and health sciences," Nursing and Health Sciences, vol. 1, pp. 241-247, January 1999.

[10] R. Harden and R. Crosby, "AMEE guide No. 20: The good teacher is more than a lecturer-the twelve roles of the teacher," Medical Teacher, vol. 22, pp. 334-347, April 2000.

[11] M. O'Sullivan, "The reconceptualization of learner-centered approaches: A Namibian case study," International Journal of Educational Development, 2003.

[12] S. Lea, D. Stephenson, and J. Troy, "Higher education students' attitudes to student centered learning: Beyond 'educational bulimia',' Studies in Higher Education, vol. 28, no. 3, pp. 321-334, March 2003.

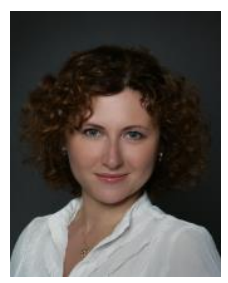

1998.
Olga A Filatova was born in Kazan, Russia in 1977. She has earned her doctorate (Ph.D.) degree in education from Russian Academy of Education in April 2002, majoring in education science. She received her bachelor's and master's degrees in secondary education with teaching majors in English as a foreign language and German. She graduated with honors summa cum laude from Tatar State University of Humanities and Education Kazan, Russia in June

She has taught English as a foreign and second language in Great Britain, Turkey, Russia and the United States. She has worked at the Intensive English Language Programs at universities, language training centers, community college, and literacy council working with ESL learners. Now she works as a visiting assistant professor of English and American culture and language program at Miami University, Oxford, OH, USA 450056 Some of her recent publications include: "The best of both worlds: What can native and non-native speaking language teachers learn from each other?" English Teacher Professional, no. 92, May 2014; “Culture's shock impact on ESL acquisition," Ohio TESOL Journal, vol. 4, no. 1, pp. 24-27, Autumn 2011; "The role of liberal arts in developing social and cultural adaptation to the dynamics of a market economy in Russia," Scientific Research of Kazan Social-Humanitarian College, pp. 1-16, Kazan, Alfa, 2005.

Her current research interests are social and cultural adaptation of international students to the new academic and cultural settings of the USA and the influence of the last on their language acquisition.

Dr. Filatova is an active member of International TESOL, Ohio TESOL, and Kentucky TESOL. She has also served as a proposal reviewer for the annual TESOL International Conference and Ohio TESOL Conference. 